\title{
Identification of a Toxin-Antitoxin System That Contributes to Persister Formation by Reducing NAD in Pseudomonas aeruginosa
}

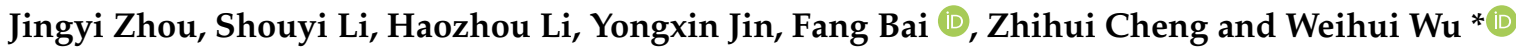 \\ State Key Laboratory of Medicinal Chemical Biology, Key Laboratory of Molecular Microbiology and Technology \\ of the Ministry of Education, Department of Microbiology, College of Life Sciences, Nankai University, \\ Tianjin 300071, China; 2120181072@mail.nankai.edu.cn (J.Z.); lishouyi@mail.nankai.edu.cn (S.L.); \\ 2120191011@mail.nankai.edu.cn (H.L.); yxjin@nankai.edu.cn (Y.J.); baifang1122@nankai.edu.cn (F.B.); \\ zhihuicheng@nankai.edu.cn (Z.C.) \\ * Correspondence: wuweihui@nankai.edu.cn
}

check for updates

Citation: Zhou, J.; Li, S.; Li, H.; Jin, Y.; Bai, F.; Cheng, Z.; Wu, W. Identification of a Toxin-Antitoxin System That Contributes to Persister Formation by Reducing NAD in Pseudomonas aeruginosa. Microorganisms 2021, 9, 753. https:// doi.org/10.3390/microorganisms 9040 753

Academic Editors: Camilla Lazzi and Giuseppantonio Maisetta

Received: 25 January 2021

Accepted: 31 March 2021

Published: 2 April 202

Publisher's Note: MDPI stays neutral with regard to jurisdictional claims in published maps and institutional affiliations.

Copyright: (c) 2021 by the authors. Licensee MDPI, Basel, Switzerland. This article is an open access article distributed under the terms and conditions of the Creative Commons Attribution (CC BY) license (https:// creativecommons.org/licenses/by/ $4.0 /)$.

\begin{abstract}
Bacterial persisters are slow-growing or dormant cells that are highly tolerant to bactericidal antibiotics and contribute to recalcitrant and chronic infections. Toxin/antitoxin (TA) systems play important roles in controlling persister formation. Here, we examined the roles of seven predicted type II TA systems in the persister formation of a Pseudomonas aeruginosa wild-type strain PA14. Overexpression of a toxin gene PA14_51010 or deletion of the cognate antitoxin gene PA14_51020 increased the bacterial tolerance to antibiotics. Co-overexpression of PA14_51010 and PA14_51020 or simultaneous deletion of the two genes resulted in a wild-type level survival rate following antibiotic treatment. The two genes were located in the same operon that was repressed by PA14_51020. We further demonstrated the interaction between PA14_51010 and PA14_51020. Sequence analysis revealed that PA14_51010 contained a conserved RES domain. Overexpression of PA14_51010 reduced the intracellular level of nicotinamide adenine dinucleotide $\left(\mathrm{NAD}^{+}\right)$. Mutation of the RES domain abolished the abilities of PA14_51010 in reducing NAD ${ }^{+}$level and promoting persister formation. In addition, overproduction of $\mathrm{NAD}^{+}$by mutation in an $n r t \mathrm{R}$ gene counteracted the effect of PA14_51010 overexpression in promoting persister formation. In combination, our results reveal a novel TA system that contributes to persister formation through reducing the intracellular $\mathrm{NAD}^{+}$level in P. aeruginosa.
\end{abstract}

Keywords: Pseudomonas aeruginosa; persister; toxin/antitoxin system

\section{Introduction}

Persister cells are dormant cells that are highly tolerant to environmental stresses, such as nutrient starvation, oxidative stress and antibiotics [1-4]. The formation of persister cells is mainly due to phenotype switch [5]. When the environmental stress is removed the dormant persister cells will resume growth [5]. Persister cells might be a major cause of chronic and recurrent bacterial infections. In addition, persister cells can be a reservoir for the evolution of antibiotic-resistant mutants [6-8].

In bacteria, toxin/antitoxin (TA) systems play important roles in persister formation [9-12]. A TA system is composed of a stable toxin and a labile antitoxin. The toxin represses bacterial growth by inhibiting important bacterial physiological processes, such as DNA replication, transcription, protein synthesis, cell wall synthesis, cell division or reducing membrane potential [13]. Normally, the function of a toxin is neutralized by its cognate antitoxin. It is proposed that the antitoxin is degraded stochastically or in response to environmental stresses, which leads to the activation of the toxin. Based on the natures of the antitoxins and their mechanisms of action, the TA systems have been classified into six types (I-VI) [9]. Recently, a group of type VII TA systems was discovered in 
Escherichia coli [14], Yersinia enterocolitica [15], Mycobacterium tuberculosis [16] and Shewanella oneidensis [17,18]. The type II TA systems are widespread in bacterial genomes [19]. For example, at least 79 and 12 type II TA systems were identified in M. tuberculosis and E. coli, respectively [20,21]. A typical type II TA system is composed of two genes in an operon that encode a toxin protein and an antitoxin protein. The activity of a type II toxin is inhibited by direct binding to its cognate antitoxin and the transcription of the TA gene operon is repressed by the antitoxin.

Pseudomonas aeruginosa is a Gram-negative opportunistic pathogen that causes acute and chronic infections in immunocompromised patients, such as those suffering AIDS or undergoing chemotherapy [22]. In addition, P. aeruginosa commonly causes pulmonary infections in cystic fibrosis (CF) patients, promoting an accelerated decline of lung function. The mucociliary deficiency in the CF airway induces the establishment of an environment which promotes $P$. aeruginosa growth [22]. It was demonstrated that the persister formation was increased in the biofilm of P. aeruginosa $[23,24]$. The roles of the TA systems in persister formation were explored in P. aeruginosa. At least four pairs of type II TA systems were identified in P. aeruginosa, namely ParD/ParE [25], HicA/HicB [26], RelE/RelB [27] and HigB/HigA [28]. The toxin ParE directly binds to and inhibits the function of the DNA gyrase [25]. The toxin HigB functions as an Rnase [28]. The deletion of the antitoxin gene hig $A$ reduces swarming motility and the production of pyochelin and pyocyanin. We previously demonstrated that the expression of the hig $A-h i g B$ operon was induced by ciprofloxacin. The overexpression of the toxin gene hig $B$ increases persister formation under ciprofloxacin treatment [29]. In addition, higB reduces the intracellular c-di-GMP level by activating the expression of three c-di-GMP hydrolysis genes, which increases expression of the type III secretion system genes and decreases biofilm formation [30]. Besides repressing the promoter of the hig $A-h i g B$ operon, higA was found to directly bind to and repress the promoter of $m v f R$, a key regulatory gene of the quorum-sensing system [31]. These results demonstrated the roles of both the toxin and the antitoxin in manipulating bacterial gene expression, besides affecting the bacterial growth and persister formation. A previous bioinformatics analysis identified seven additional putative type II TA systems on the genome of a wild-type P. aeruginosa stain PA14, namely PA14_51010/PA14_51020, PA14_40220/PA14_40210, PA14_21710/PA14_21720, PA14_28790/PA14_28780, PA14_60050/PA14_60040, PA14_71340/PA14_71330 and PA14_28120/PA14_28130[20].

In this study, we examined the roles of these predicted type II TA systems in persister formation. PA14_51010/PA14_51020 (PA1030/PA1029 on the PAO1 genome) was found to modulate persister formation by reducing the intracellular $\mathrm{NAD}^{+}$level. Our results reveal a novel TA system involved in the persister formation by influencing the key molecule in energy metabolism in $P$. aeruginosa.

\section{Materials and Methods}

\subsection{Strains and Plasmids}

The strains, plasmids and primers used in this study are listed in Table 1 . All strains were cultured in the Luria-Bertani (LB) broth $(10 \mathrm{~g} / \mathrm{L}$ tryptone, $5 \mathrm{~g} / \mathrm{L}$ yeast extract, $5 \mathrm{~g} / \mathrm{L}$ $\mathrm{NaCl}, \mathrm{pH} 7.4$ ) (BBI LifeScience, Shanghai, China) at $37^{\circ} \mathrm{C}$. When needed, antibiotics were used at the following concentrations ( $\mu \mathrm{g} / \mathrm{mL})$ : for E. coli, ampicillin 100, gentamicin 10 and tetracycline 10; for P. aeruginosa, carbenicillin 150, gentamicin 50 and tetracycline 50 (Macklin, Shanghai, China). Isopropyl- $\beta$-d-thiogalactoside (IPTG) (TaKaRa, Dalian, China) was added to LB at indicated concentrations. 
Table 1. Bacterial strains, plasmids and primers used in this study.

\begin{tabular}{|c|c|c|}
\hline Strain & Description & Source (Reference) \\
\hline \multicolumn{3}{|l|}{ P. aeruginosa } \\
\hline PA14 & Wild-type strain of Pseudomonas aeruginosa & [32] \\
\hline$\triangle P A 14 \_51020$ & PA14 deleted of PA14_51020 & This study \\
\hline$\triangle P A 14 \_51010$ & PA14 deleted of PA14_51010 & This study \\
\hline$\triangle P A 14 \_51020 \Delta P A 14 \_51010$ & PA14 deleted of PA14_51020 and PA14_51010 & This study \\
\hline \multicolumn{3}{|l|}{ Plasmid } \\
\hline pEX18Tc & Gene replacement vector; $\mathrm{Tc}^{\mathrm{r}}$ & [33] \\
\hline pMMB67EH & Expression vector with tac promoter; Amp ${ }^{r}$ & [34] \\
\hline pUCP20-lacZ & Promoterless lacZ fusion vector; Amp ${ }^{\mathrm{r}}$ & [35] \\
\hline pMMB67EH-PA14_51010-Flag & $\begin{array}{l}\text { PA14_51010 gene with Flag-tag driven by tac promoter on } \\
\text { pMMB67EH; Amp }{ }^{\text {r }}\end{array}$ & This study \\
\hline pMMB67EH-PA14_40220-Flag & $\begin{array}{l}\text { PA14_40220 gene with Flag-tag driven by tac promoter on } \\
\text { pMMB67EH; Amp }^{\text {r }}\end{array}$ & This study \\
\hline pMMB67EH-PA14_21710-Flag & $\begin{array}{c}\text { PA14_21710 gene with Flag-tag driven by tac promoter on } \\
\text { pMMB67EH; Amp }{ }^{r}\end{array}$ & This study \\
\hline pMMB67EH-PA14_28120-Flag & $\begin{array}{l}\text { PA14_28120 gene with Flag-tag driven by tac promoter on } \\
\text { pMMB67EH; Amp }^{r}\end{array}$ & This study \\
\hline pMMB67EH-PA14_28790-Flag & $\begin{array}{l}\text { PA14_28790 gene with Flag-tag driven by tac promoter on } \\
\text { pMMB67EH; Amp }^{r}\end{array}$ & This study \\
\hline pMMB67EH-PA14_60050-Flag & $\begin{array}{l}\text { PA14_60050 gene with Flag-tag driven by tac promoter on } \\
\text { pMMB67EH; Amp }{ }^{\text {r }}\end{array}$ & This study \\
\hline pMMB67EH-PA14_71340-Flag & $\begin{array}{l}\text { PA14_71340 gene with Flag-tag driven by tac promoter on } \\
\text { pMMB67EH; Amp }^{r}\end{array}$ & This study \\
\hline pMMB67EH-GST-His & $\begin{array}{l}\text { GST with His-tag driven by tac promoter on } \\
\text { pMMB67EH; Amp }{ }^{\mathrm{r}}\end{array}$ & [36] \\
\hline pMMB67EH-GST-PA14_51020-His & $\begin{array}{l}\text { PA14_51020 gene with His-tag fused to GST driven by tac } \\
\text { promoter on pMMB67EH; Amp }{ }^{\text {r }}\end{array}$ & This study \\
\hline pEX18Tc- $\triangle P A 14 \_51020$ & PA14_51020 gene of PA14 deletion on pEX18Tc; $\mathrm{Tc}^{\mathrm{r}}$ & This study \\
\hline pEX18Tc- $\triangle P A 14 \_51010$ & PA14_51010 gene of PA14 deletion on $\mathrm{pEX18Tc}$; $\mathrm{Tc}^{\mathrm{r}}$ & This study \\
\hline pEX18Tc- $\triangle P A 14 \_51020 \Delta P A 14 \_51010$ & $\begin{array}{l}\text { PA14_51020 and PA14_51010 gene of PA14 deletion on } \\
\text { pEX18Tc; Tc }{ }^{r}\end{array}$ & This study \\
\hline pUCP20-P PA14_51020-lacZ & $\begin{array}{c}\text { PA14_51020 promoter of PA14 on a promoterless lacZ fusion } \\
\text { vector; Amp }{ }^{\text {r }}\end{array}$ & This study \\
\hline pMMB67EH-PA14_51020 & $\begin{array}{l}\text { PA14_51020 gene driven by tac promoter on pMMB67EH; } \\
\text { Amp }^{\mathrm{r}}\end{array}$ & This study \\
\hline $\begin{array}{l}\text { pMMB67EH-operon } \\
(\text { PA14_51020-PA14_51010) }\end{array}$ & $\begin{array}{c}\text { The operon (PA14_51020-PA14_51010) driven by tac promoter } \\
\text { on pMMB67EH; Amp }{ }^{\mathrm{r}}\end{array}$ & This study \\
\hline pMMB67EH-PA14_51010 (RES-A) & $\begin{array}{l}\text { PA14_51010 gene with simultaneous replacement of the R, E, S } \\
\text { residues with A residues driven by tac promoter on } \\
\text { pMMB67EH; Amp }{ }^{\text {p }}\end{array}$ & This study \\
\hline Primer & Sequence $5^{\prime}-3^{\prime}$ & Purpose \\
\hline EcoRI-PA14_51020-up-F & CCGGAATTCGCTGGAGTTGCTGACCG & $\begin{array}{c}\text { PA14_51020, } \\
\text { PA14_51010 deletion }\end{array}$ \\
\hline KpnI-PA14_51020-up-R & CGGGGTACCGCCCCAATTGCTCGC & $\begin{array}{c}\text { PA14_51020, } \\
\text { PA14_51010 deletion }\end{array}$ \\
\hline KpnI-PA14_51020-down-F & CGGGGTACCACGCCTGTCACGGAAAAG & PA14_51020 deletion \\
\hline HindIII-PA14_51020-down-F & CCCAAGCTTTCGCCGAAGCCTCTTGC & PA14_51020 deletion \\
\hline EcoRI-PA14_51010-up-F & CCGGAATTCTCAGCAGCATCCGTCGCGAT & PA14_51010 deletion \\
\hline KpnI-PA14_51010-up-R & CGGGGTACCCTTCCGCCCCTCGCTTCCTG & PA14_51010 deletion \\
\hline KpnI-PA14_51010-down-F & CGGGGTACCGAGCTGTTCCTGGTGG & $\begin{array}{l}\text { PA14_51020 and } \\
\text { PA14_51010 deletion }\end{array}$ \\
\hline HindIII-PA14_51010-down-R & CCCAAGCTTGACGCACTTCCTCTTCC & $\begin{array}{c}\text { PA14_51020 and } \\
\text { PA14_51010 deletion }\end{array}$ \\
\hline SmaI-P ${ }_{P A 14 \_51020-\mathrm{F}}$ & TCCCCCGGGGGCAATGGGCCGATCGAATC & $\begin{array}{l}\text { PA14_51020 promoter } \\
\text { cloning }\end{array}$ \\
\hline
\end{tabular}


Table 1. Cont.

\begin{tabular}{|c|c|c|}
\hline Strain & Description & Source (Reference) \\
\hline BamHI-P PA14_51020-R & CGCGGATCCCCCCAATTGCTCGCGCGCGG & $\begin{array}{l}\text { PA14_51020 promoter } \\
\text { cloning }\end{array}$ \\
\hline EcoRI-PA14_51010-F & CCGGAATTCTCCGACACCACAGGAAGCGA & PA14_51010 cloning \\
\hline HindIII-PA14_51010-R & $\begin{array}{l}\text { CCCAAGCTTTCATTTATCATCATCATCTTTGTAA } \\
\text { TCCGCCGGATGCGGCA }\end{array}$ & PA14_51010 cloning \\
\hline BamHI-PA14_51020-F & CGCGGATCCACGCAGCTCGAACTGGCCGG & PA14_51020 cloning \\
\hline HindIII-PA14_51020-R & $\begin{array}{c}\text { CCCAAGCTTTCAGTGGTGGTGGTGGTGGTGGA } \\
\text { CCTTGCCGCGGATCGCAT }\end{array}$ & PA14_51020 cloning \\
\hline EcoRI-GST-F & $\begin{array}{l}\text { CCGGAATTCTTTAAGAAGGAGATATAATGTCCCC } \\
\text { TATACTAGGTTA }\end{array}$ & PA14_51020 cloning \\
\hline BamHI-GST-R & CGCGGATCCACCAGAACCACTAGTTGAAC & PA14_51020 cloning \\
\hline BamHI-PA14_40220-F & CGCGGATCCGCTCGTTTCACCGGTAGCGG & PA14_40220 cloning \\
\hline HindIII-PA14_40220-R & $\begin{array}{c}\text { CCCAAGCTTCTATTTATCATCATCATCTTTGTAA } \\
\text { TCGGCGTCGCGCCGA }\end{array}$ & PA14_40220 cloning \\
\hline BamHI-PA14_21710-F & CGCGGATCCACGCTCTGATGGGAGCGGAG & PA14_21710 cloning \\
\hline HindIII-PA14_21710-R & $\begin{array}{c}\text { CCCAAGCTTTCATTTATCATCATCATCTTTGTAA } \\
\text { TCGCCGGTGAAGCTGGCT }\end{array}$ & PA14_21710 cloning \\
\hline EcoRI-PA14_28120-F & CCGGAATTCCCGCCAGCCTGTACGCACAA & PA14_28120 cloning \\
\hline BamHI-PA14_28120-R & $\begin{array}{l}\text { CGCGGATCCTCATTTATCATCATCATCTTTGTAA } \\
\text { TCGCCTCGCGCCAGT }\end{array}$ & PA14_28120 cloning \\
\hline EcoRI-PA14_28790-F & CCGGAATTCCAGCATATGCGGGAGCTGTT & PA14_28790 cloning \\
\hline HindIII-PA14_28790-R & $\begin{array}{c}\text { CCCAAGCTTTCATTTATCATCATCATCTTTGTAA } \\
\text { TCGTGAGTACCAGCCC }\end{array}$ & PA14_28790 cloning \\
\hline EcoRI-PA14_60050-F & CCGGAATTCGAGCTCGGCAACCAGGCGAG & PA14_60050 cloning \\
\hline HindIII-PA14_60050-R & $\begin{array}{c}\text { CCCAAGCTTTCATTTATCATCATCATCTTTGTAA } \\
\text { TCTCGTTGGGGCAGGT }\end{array}$ & PA14_60050 cloning \\
\hline EcoRI-PA14_71340-F & CCGGAATTCCCCCGCTCCACCCTTTCCCA & PA14_71340 cloning \\
\hline HindIII-PA14_71340-R & $\begin{array}{c}\text { CCCAAGCTTTCATTTATCATCATCATCTTTGTAA } \\
\text { TCTTGAGGTTGCT }\end{array}$ & PA14_71340 cloning \\
\hline EMSA-upstream-F & GTTTTTCTCTCTATCACGCC & EMSA \\
\hline EMSA-upstream-R & CCCCAATTGCTCGCGCGCGG & EMSA \\
\hline EMSA-inside-F & CGGGCTGGAAGGTGGAGCGG & EMSA \\
\hline EMSA-inside-R & CGCGGGCGTGAACAGGGCGA & EMSA \\
\hline PA14_51010-F & GAGCCAAGCCTGTTCTAC & qRT-PCR \\
\hline PA14_51010-R & CAGGACACAACGGTAATACG & qRT-PCR \\
\hline PA14_51020-F & CACTCССАAССАТCAC & qRT-PCR \\
\hline PA14_51020-R & AGGTATTCCAGCACAT & qRT-PCR \\
\hline
\end{tabular}

\subsection{Construction of Plasmids and Mutation Strains}

For the overexpression of PA14_51010, the PA14_51010 coding region with its natural Shine-Dalgarno (SD) sequence was amplified by PCR using the PA14 genomic DNA as the template with the primers listed in Table 1 . The PCR product was cloned into the plasmid pMMB67EH. For the overexpression of PA14_51020, the PA14_51020 coding region was amplified by PCR using the PA14 genomic DNA as the template and cloned into pMMB67EH containing the gst gene [36], resulting in an N-terminus GST tagged PA14_51020.

To construct the transcriptional fusion of the PA14_51020 promoter and the lacZ gene, a 500 bp DNA fragment upstream of the PA14_51020 gene start codon was amplified by PCR with the primers listed in Table 1. The PCR product was cloned into the pUCP20-lacZ plasmid [35].

For the deletion of the PA14_51020 gene, a 986-bp fragment and a 1019-bp fragment upstream and downstream of the PA14_51020 gene coding region were amplified by PCR using the PA14 genomic DNA as the template. The PCR products were ligated into the pEX18Tc plasmid. Deletion of the PA14_51020 gene in P. aeruginosa was performed as 
previously described [37]. The same method was used to construct the $\triangle P A 14 \_51010$ and $\triangle P A 14 \_51010 \Delta P A 14 \_51020$ mutants.

\subsection{Bacteria Killing Assay}

Overnight bacterial cultures of the indicated strains were diluted 100-fold in fresh LB. To induce the expression of the cloned genes, $1 \mathrm{mM}$ IPTG (TaKaRa, Dalian, China) was added to the culture medium. The bacteria were cultured to an $\mathrm{OD}_{600}$ of $0.8-1.0$, and then treated with $0.5 \mu \mathrm{g} / \mathrm{mL}$ ciprofloxacin (BBI LifeScience, Shanghai, China) or $5 \mu \mathrm{g} / \mathrm{mL}$ tobramycin (Meilunbio, Dalian, China). At indicated time points, the bacterial samples were taken for serial dilution and plating. The plate was incubated at $37^{\circ} \mathrm{C}$ for $24 \mathrm{~h}$ before colony counting.

\subsection{RNA Isolation and Quantitative Real-Time PCR}

Total bacterial RNA was isolated with the ZOMANBIO RNA Rapid Extraction Kit (Zomanbio, Beijing, China). A Prime-Script Reverse Transcriptase (TaKaRa, Dalian, China) and random primers were used to synthesize cDNA from each RNA sample as instructed by the manufacturer. Quantitative RT-PCR was performed with a CFX real-time system (Bio-Rad, Hercules, CA, USA), using SYBR Premix ExTaq II (TaKaRa, Dalian, China) and indicated primers (Table 1). The $30 \mathrm{~S}$ subunit ribosomal protein coding gene $r p s L$ was used as an internal control.

\subsection{Transcriptional Reporter Assay}

Bacteria of the indicated strains were grown to an $\mathrm{OD}_{600}$ of 1.0 in $\mathrm{LB}$ at $37^{\circ} \mathrm{C} .0 .5 \mathrm{~mL}$ of the bacterial culture was subjected to centrifugation at $12,000 \times \mathrm{g}$ for $1 \mathrm{~min}$. The bacteria were resuspended in $1.5 \mathrm{~mL} \mathrm{Z}$ buffer $\left(60 \mathrm{mM} \mathrm{Na}_{2} \mathrm{HPO}_{4}, 60 \mathrm{mM} \mathrm{NaH}_{2} \mathrm{PO}_{4}, 1 \mathrm{mM} \mathrm{MgSO}_{4}\right.$, $10 \mathrm{mM} \mathrm{KCl}, 50 \mathrm{mM} \beta$-mercaptoethanol (pH 7.0); BBI Life Sciences, Shanghai, China). The $\beta$-galactosidase activity was determined by ortho-nitrophenyl- galactopyranoside (ONPG) (BBI Life Sciences, Shanghai, China) as described previously [38].

\subsection{Expression and Purification of the PA14_51020 Protein}

DH5 $\alpha$ cells carrying the pMMB67EH-gst-PA14_51020-His were grown in LB at $37^{\circ} \mathrm{C}$. When the $\mathrm{OD}_{600}$ reached approximately $0.6,1 \mathrm{mM}$ IPTG was added to the medium and the bacteria were kept growing for $4 \mathrm{~h}$ at $37^{\circ} \mathrm{C}$. The bacteria were collected by centrifugation at $6000 \times \mathrm{g}$ for $10 \mathrm{~min}$ at $4{ }^{\circ} \mathrm{C}$, followed by resuspension in the lysis buffer $(20 \mathrm{mM}$ Tris$\mathrm{HCl}, 150 \mathrm{mM} \mathrm{NaCl}, 3 \mathrm{mM} \beta$-mercaptoethanol, $10 \mathrm{mM}$ imidazole, 0.5\% NP-40 (Solarbio, Beijing, China), $\mathrm{pH}$ 8.0) and sonication. The lysate was centrifuged at 12,000 $\mathrm{g}$ for $10 \mathrm{~min}$ at $4{ }^{\circ} \mathrm{C}$. The supernatant was incubated with Ni-NTA beads (Qiagen, Düsseldorf, North Rhine-Westphalia, GER) for $2 \mathrm{~h}$ at room temperature. The Ni-NTA beads were washed sequentially with the lysis buffer containing $50 \mathrm{mM}$ and $100 \mathrm{mM}$ imidazole. The bound proteins were eluted by the lysis buffer containing $300 \mathrm{mM}$ imidazole. The purity of the eluted protein was examined by SDS-PAGE, and the protein concentrations were quantified by a bicinchoninic acid (BCA) protein assay (Beyotime, Shanghai, China).

\subsection{Electrophoretic Mobility Shift Assay (EMSA)}

The EMSA was performed as previously described [39]. A 200 bp DNA fragment upstream of the PA14_51020 coding region or inside of the PA14_51010 coding region was amplified by PCR with primers listed in Table 1. An amount of $20 \mathrm{ng}$ of the purified PCR product was incubated with the purified GST-PA14_51020-His protein at the concentration of 8,16 or $32 \mathrm{mM}$ in the binding buffer $(10 \mathrm{mM}$ Tris- $\mathrm{HCl}, 5 \mathrm{mM} \mathrm{CaCl}, 100 \mathrm{mM} \mathrm{NaCl}, 4 \%$ glycerol (promega, Beijing, China), 1 mM EDTA (solarbio, Beijing, China), 10 mM DTT (solarbio, Beijing, China), pH 7.5) in a total volume of $20 \mu \mathrm{L}$. The mixture was incubated on ice for $15 \mathrm{~min}$. The purified GST protein was used as a negative control. The samples were loaded onto an $8 \%$ native polyacrylamide gel in $0.5 \times$ Tris-borate-EDTA (TBE) buffer that had been prerun on ice for one hour. The electrophoresis was performed on ice at 120 
$\mathrm{V}$ for $110 \mathrm{~min}$, followed by staining in $0.5 \times \mathrm{TBE}$ containing $2 \mu \mathrm{g} / \mathrm{mL}$ ethidium bromide. The bands were observed with a molecular imager ChemiDoc ${ }^{\mathrm{TM}} \mathrm{XRS}+(\mathrm{Bio}-\mathrm{Rad}$, Hercules, CA, USA).

\subsection{Pull Down Assay}

The GST-His and GST-PA14_51020-His proteins were purified by the Ni-NTA beads (Qiagen, Düsseldorf, North Rhine-Westphalia, GER) as aforementioned. The E. coli strain containing the pMMB67EH-PA14_51010-Flag was grown to an $\mathrm{OD}_{600}$ of 0.6 and then kept growing with $1 \mathrm{mM}$ IPTG for $4 \mathrm{~h}$ at $37^{\circ} \mathrm{C}$. $600 \mathrm{~mL}$ of the bacteria was collected by centrifugation at 10,000 $\mathrm{g}$ for $1 \mathrm{~min}$ and resuspended in $12 \mathrm{~mL}$ lysis buffer $(20 \mathrm{mM}$ Tris- $\mathrm{HCl}$, $150 \mathrm{mM} \mathrm{NaCl}, 3 \mathrm{mM} \beta$-mercaptoethanol, $10 \mathrm{mM}$ imidazole, 0.5\% NP-40, pH 8.0). An amount of $100 \mu \mathrm{g}$ of the purified GST-His or GST-PA14_51020-His proteins was mixed with $4 \mathrm{~mL}$ of the bacterial lysate, followed by incubation with the Ni-NTA beads at $4{ }^{\circ} \mathrm{C}$ overnight. The Ni-NTA beads were then washed 5 times with the lysis buffer containing $50 \mathrm{mM}$ imidazole. The proteins were eluted with the lysis buffer containing $300 \mathrm{mM}$ imidazole. The samples were examined with an Anti-GST antibody (Applygen, Beijing, China) and an Anti-Flag antibody (Sigma, St. Louis, MO, USA).

\section{Results}

\subsection{Identification of Novel Persister Formation Related Genes}

In order to examine the roles of the predicted TA systems in persister formation, we overexpressed the potential toxin genes in wild-type PA14, including PA14_28120, PA14_21710, PA14_28790, PA14_40220,PA14_51010, PA14_60050 and PA14_71340. Previously, we determined the minimum inhibitory concentrations (MICs) of tobramycin and ciprofloxacin against the wild-type PA14 as 1 and $0.25 \mu \mathrm{g} / \mathrm{mL}$, respectively $[29,36]$. Overexpression of PA14_51010 increased the bacterial survival rate by approximately 100fold upon treatment with $5 \mu \mathrm{g} / \mathrm{mL}$ tobramycin or $0.5 \mu \mathrm{g} / \mathrm{mL}$ ciprofloxacin (Figure 1A,B). Overexpression of PA14_28120 increased the survival rate by approximately 10-fold after the bacteria were treated with tobramycin for $8 \mathrm{~h}$ (Figure 1A), whereas overexpression of the other five genes did not affect the bacterial survival rates under ciprofloxacin treatment (Figure 1A,B). Notably, overexpression of PA14_21710, PA14_28790,PA14_40220 and PA14_60050 reduced the survival rates 2, 4 or $6 \mathrm{~h}$ after tobramycin treatment. However, the survival rates of strains overexpressing these genes were similar to PA14 containing the empty vector after $8 \mathrm{~h}$ (Figure 1A). These results suggest an important role of PA14_51010 in persister formation, thus we focused our following studies on this gene.

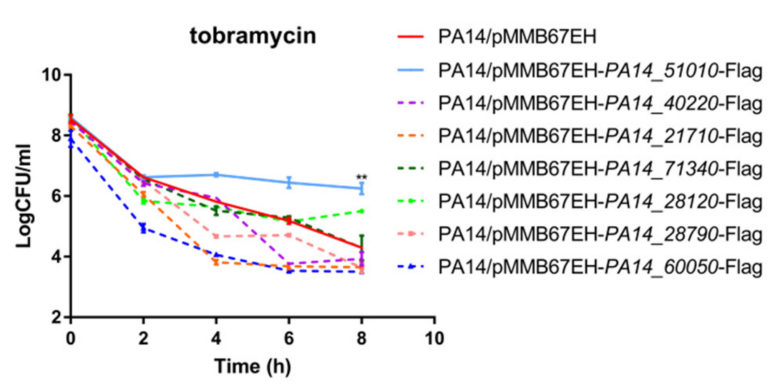

(A)

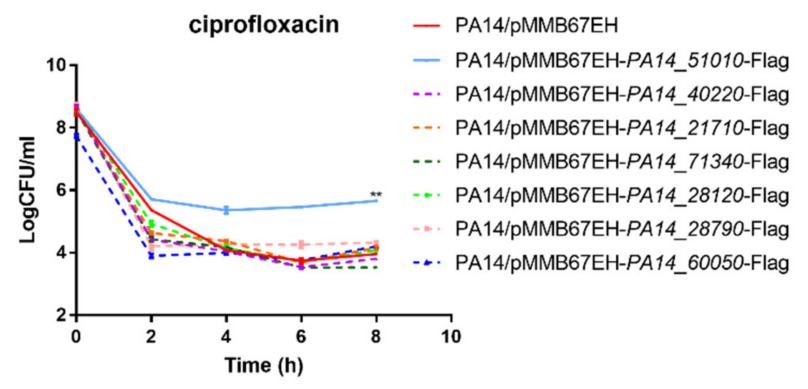

(B)

Figure 1. Identification of novel persister formation related genes. Wild-type PA14 overexpressing the indicated genes were treated with $5 \mu \mathrm{g} / \mathrm{mL}$ tobramycin (A) or $0.5 \mu \mathrm{g} / \mathrm{mL}$ ciprofloxacin (B). At indicated time points the live bacteria numbers were determined by serial dilution and plating. Data represent the results from three independent experiments. ${ }^{* *}, p<0.01$ compared to the other samples by Student's $t$ test. 


\subsection{PA14_51020 Regulates the Operon of PA14_51020 and PA14_51010}

The type II toxin and antitoxin genes usually form one operon that is negatively regulated by the antitoxin. On the PA14 genome, PA14_51010 is located next to PA14_51020 and the two genes are transcribed in the same direction (Figure 2A) [22]. RT-PCR analysis confirmed that PA14_51020 and PA14_51010 were in the same operon (Figure 2B). To examine whether PA14_51020 negatively regulates the expression of the operon, we deleted the PA14_51020 gene in wild-type PA14. The mRNA level of PA14_51010 was higher in the $\triangle P A 14$ 51020 mutant than that in wild-type PA14 (Figure 2C). We then constructed a transcriptional fusion of lac $Z$ with the promoter of the operon (designated as $P_{P A 14 \text { _51020-lac } Z \text { ) }}$ and transferred it into wild-type PA14 and the $\triangle P A 14$ 51020 mutant. The $\beta$-galactosidase activity was higher in the $\triangle P A 14$ 51020 mutant than that in wild-type PA14 (Figure 2D). In addition, an electrophoretic mobility shift assay (EMSA) demonstrated an interaction between PA14_51020 and the promoter region of the operon but not the fragment inside the coding region of PA14_51010 (Figure 2E). These results suggest that PA14_51020 and PA14_51010 are in the same operon, which is directly repressed by PA14_51020.

\subsection{PA14_51020 and PA14_51010 Regulates Persister Formation}

To verify that PA14_51020 and PA14_51010 function as a toxin-antitoxin system, we examined the interaction between PA14_51020 and PA14_51010 by a pull-down assay. The lysate of DH5 $\alpha$ cells overexpressing PA14_51010-Flag was incubated with purified $6 \times$ His tagged GST (GST-His) or GST-PA14_51020 (GST-PA14_51020-His). In the eluted protein samples, there was a higher amount of GST-His than GST-PA14_51020-His, indicating that GST-PA14_51020-His might be more labile than GST-His in the experimental process. Nevertheless, the PA14_51010-Flag was co-purified with GST-PA14_51020-His but not GST-His, indicating an interaction between PA14_51010 and PA14_51020 (Figure 3). These result indicate that PA14_51010 and PA14_51020 could function as a type II TA system.

We then examined whether PA14_51020 could suppress the function of PA14_51010 in promoting persister formation. Compared to the strain overexpressing PA14_51010, co-expressing PA14_51010 and PA14_51020 reduced the bacterial survival rates to the wild-type level following treatment with ciprofloxacin and tobramycin (Figure 4A,B). In wild-type PA14, deletion of PA14_51020 increased the bacterial survival rate by approximately 60-fold following the treatment of tobramycin, whereas simultaneous deletion of PA14_51010 and PA14_51020 reduced the survival rate to the wild-type level (Figure 4C). However, the survival rate of the $\triangle P A 14 \_51020$ mutant was similar to the wild-type strain under the treatment of ciprofloxacin (Figure 4D). To understand the discrepancy between the PA14_51010 overexpressing strain and the $\triangle P A 14 \_51020$ mutant, we determined the expression levels of PA14_51010 by real time PCR. The mRNA level of PA14_51010 was approximately 5-fold lower in the $\triangle P A 14 \_51020$ mutant than that in the PA14_51010 overexpressing strain (Figure 4E), which might result in the different survival rates in the two strains. In combination, these results demonstrate that PA14_51020 and PA14_51010 comprise a toxin and antitoxin system that might play a more important role in promoting persister formation under the treatment of tobramycin than ciprofloxacin. 


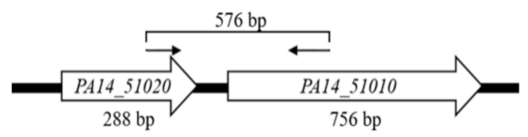

(A)

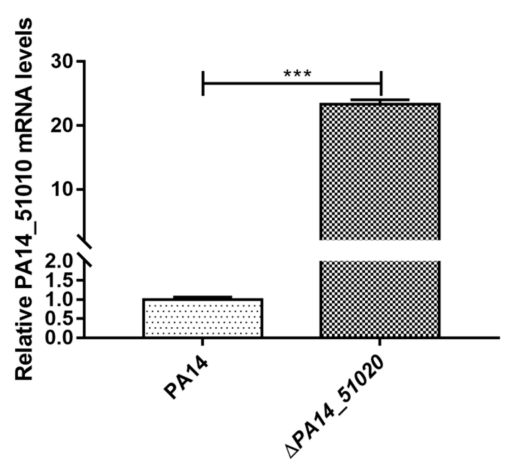

(C)



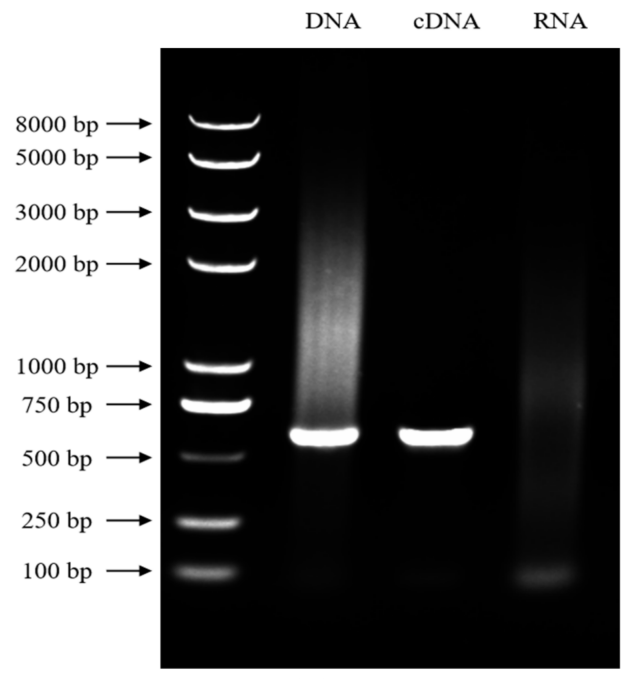

(B)

$P_{P A 14 \text { 51020 - lacZ }}$

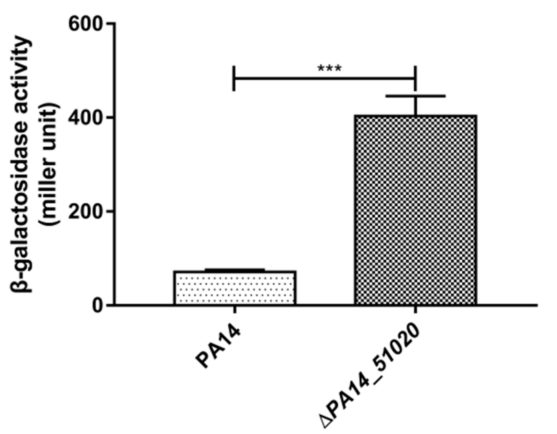

(D)

200 bp inside PA14 51010

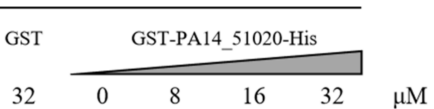

$\begin{array}{llllll}32 & 0 & 8 & 16 & 32 & \mu \mathrm{M}\end{array}$

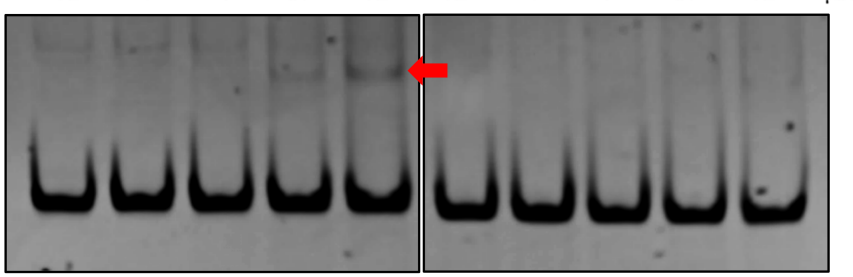

(E)

Figure 2. PA14_51020 regulates the operon of PA14_51020 and PA14_51010. (A) Sketch map of the PA14_51020-PA14_51010 operon. Arrows indicate the location and direction of primers used in RT-PCR. Sequences of the primers (PA14_51020-F and PA14_51010-R) were listed in Table 1. The size of the PCR product is $576 \mathrm{bp}$. (B) Total RNA was isolated from PA14, followed by the synthesis of cDNA. The cDNA was used as the template in PCR. The chromosomal DNA and total RNA were used as a positive control and a negative control, respectively. (C) Wild-type PA14 and the $\triangle P A 14$ _51020 mutant were grown to an $\mathrm{OD}_{600}$ of 1.0, followed by RNA isolation. The mRNA levels of PA14_51010 were determined by quantitative RT-PCR. The ribosomal protein coding gene $r p s L$ was used as an internal control. (D) The $\beta$-galactosidase activity in PA14 and the $\triangle P A 14 \_51020$ mutant carrying the $P_{P A 14}$ 51020-lacZ transcriptional fusion. Data represent the results from three independent experiments. ${ }^{* *}, p<0.001$, by Student's $t$ test. (E) Purified GST-PA14_51020-His protein was incubated with 20 ng of the DNA fragment of the promoter region of the PA14_51020-PA14_51010 operon or inside the PA14_51010 open reading frame. The DNA bands were observed by ethidium bromide staining. The purified GST-His protein was used as a negative control. The arrow indicates the protein-DNA probe complex. 


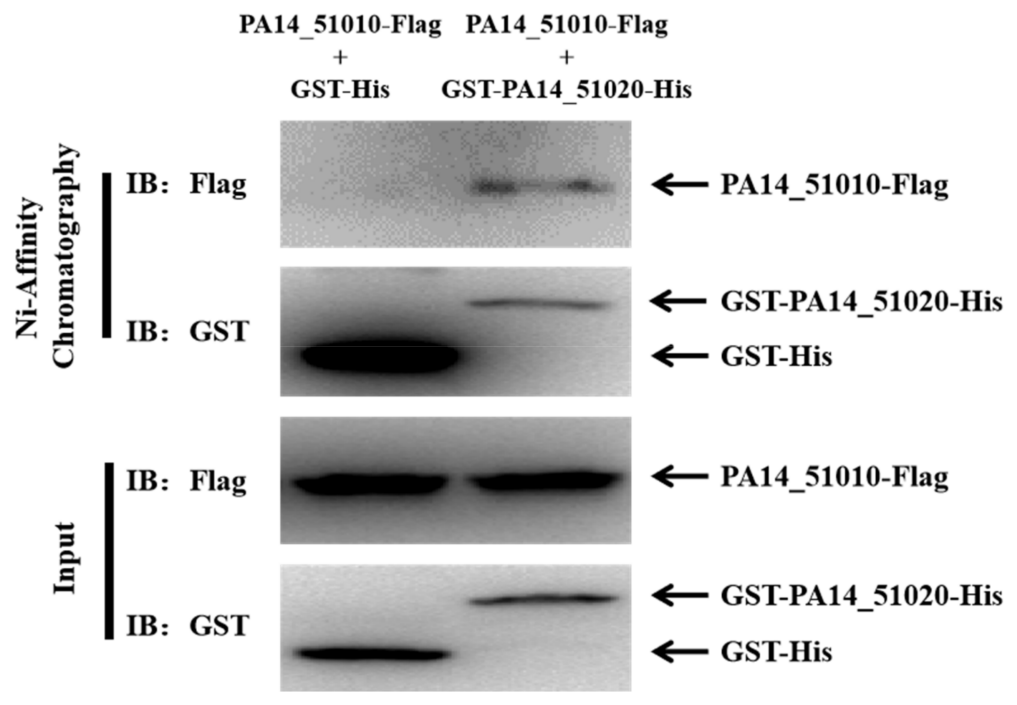

Figure 3. Interaction between PA14_51020 and PA14_51010. DH5 $\alpha$ cells carrying pMMB67EH-GSTHis or pMMB67EH-GST-PA14_51020-His were grown to an $\mathrm{OD}_{600}$ of 0.6 and then grown in the presence of $1 \mathrm{mM}$ isopropyl- $\beta$-d-thiogalactoside (IPTG) for $4 \mathrm{~h}$. The bacteria were lysed and subjected to chromatography with Ni-NTA beads. The bound protein was eluted by the elution buffer. The lysate of DH5 $\alpha$ cells expressing the pMMB67EH-PA14_51010-Flag was mixed with same amount of the purified GST-His or GST-PA14_51020-His. Then, the mixtures were subjected to chromatography with Ni-NTA beads. The Flag-tagged PA14_51010, GST-tagged PA14_51020 and GST were detected by Western blot.

\subsection{PA14_51010 Promotes Persister Formation by Reducing the Intracellular Level of NAD ${ }^{+}$}

PA14_51010 contains a conserved RES domain (Figure 5A). Overexpression of PA14_51010 did not reduce the bacterial growth rate in LB (Figure S1). On the PA14 genome, the start codon of PA14_51010 is GTG [40], which is the same as the orthologues genes (designated as res) in P. luminescens, M. tuberculosis and Pseudomonas putida [41]. A previous study in P. luminescens demonstrated that overexpression of the res gene did not affect the bacterial growth rate either [41]. However, substitution of the GTG with ATG reduced the growth rate, which might be due to the enhanced translation of the res gene [41]. Consistent with the previous study, the replacement of the start codon of the PA14_51010 gene with ATG increased the protein level and reduced the bacterial growth rate (Figure $\mathrm{S} 1$ ).

Previous studies revealed $\mathrm{NAD}^{+}$degradation activities of the bacterial RES toxins [41,42]. Overexpression of PA14_51010 in wild-type PA14 indeed reduced the intracellular level of $\mathrm{NAD}^{+}$, which was restored by co-expression of PA14_51020 (Figure 5B). Simultaneous replacement of the $R, E$ and $S$ residues with A residues did not reduce the level of protein PA14_51010-Flag (Figure 5C), but abolished the NAD ${ }^{+}$-reducing (Figure 5B) and persister formation-promoting activity of PA14_51010 (Figure 5D,E).

If PA14_51010 promotes persister formation by reducing $\mathrm{NAD}^{+}$, overproduction of $\mathrm{NAD}^{+}$should neutralize the function of PA14_51010. In most bacteria, NAD ${ }^{+}$is synthesized through a de novo synthesis pathway and salvage pathways I and/or II [43]. A conserved transcriptional regulator NrtR controls the expression of genes involved in $\mathrm{NAD}^{+}$biosynthesis [44]. In Mycobacterium smegmatis, mutation of the $n r t \mathrm{R}$ gene increases the expression of $\mathrm{NAD}^{+}$biosynthesis genes and intracellular $\mathrm{NAD}^{+}$level [44]. In P. aeruginosa, NrtR directly represses genes involved in the $\mathrm{NAD}^{+}$synthesis salvage pathway I, including $p n c A$, pncB1, nadE and nadD2 [45]. A previous study demonstrated that mutation of the $n r t R$ gene results in upregulation of these genes and higher ratios of $\mathrm{NAD}^{+}$to NADH and $\mathrm{NADP}^{+}$to NADPH at the stationary growth phase [45]. We found that the total $\mathrm{NAD}^{+}$ level was increased in an $n r t R:: T n$ mutant at the exponential growth phase $\left(\mathrm{OD}_{600}=1.0\right)$ (Figure 6A). Overexpression of PA14_51010 in the $n r t R:: T n$ mutant reduced the NAD ${ }^{+}$ 
level, which however was higher than that in the wild-type PA14 (Figure 5C, Figure 6A). Upon treatment with tobramycin, the survival rate of the $n r t R:: T n$ mutant containing the empty vector or overexpressing PA14_51010 were higher than that of the wild-type strain containing the empty vector at the 6-h time point, but reduced to the wild-type level after 8 $\mathrm{h}$ (Figure 6B). In the presence of ciprofloxacin, overexpression of PA14_51010 in the $n r t R:: T n$ mutant increased the survival rate at the 4- and 6-h time points, but resulted in a similar survival rate as the strains containing the empty vector at the 8-h time point (Figure 6C). In contrast, overexpression of PA14_51010 in the wild-type strain steadily increased the survival rates (Figure 6B,C). Taken together, these results demonstrate that PA14_51010 promotes persister formation by reducing the intracellular level of $\mathrm{NAD}^{+}$.

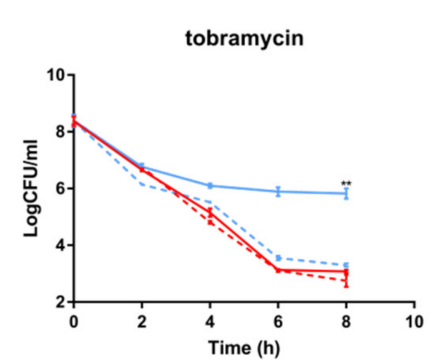

(A)

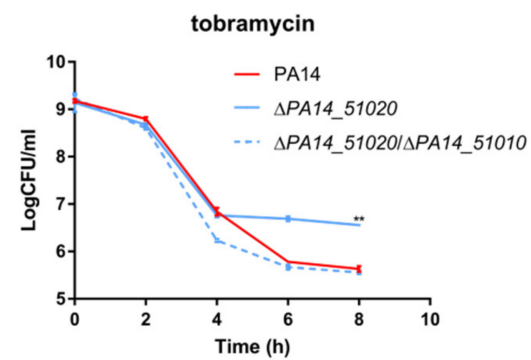

(C)

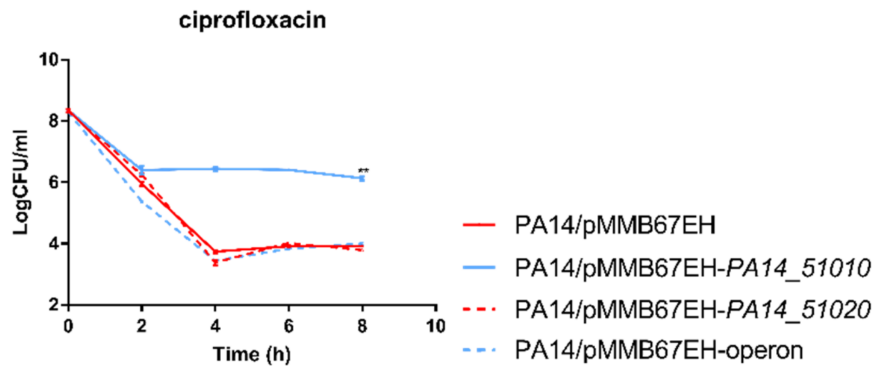

(B)

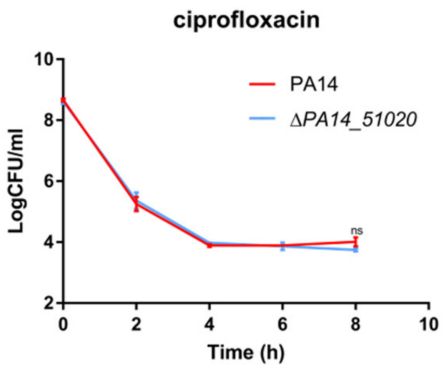

(D)

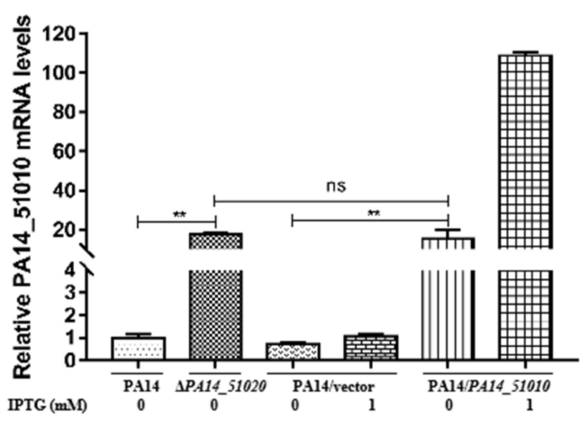

(E)

Figure 4. PA14_51020 and PA14_51010 regulate persister formation. (A,B) Wild-type PA14 carrying pMMB67EH, pMMB67EH-PA14_51010, pMMB67EH-PA14_51020 or the pMMB67EH-operon (PA14_51020-PA14_51010) were treated with $5 \mu \mathrm{g} / \mathrm{mL}$ tobramycin (A) or $0.5 \mu \mathrm{g} / \mathrm{mL}$ ciprofloxacin (B). At indicated time points the live bacteria numbers were determined by serial dilution and plating assay. (C) Wild-type PA14 and the $\triangle P A 14 \_51020$ and $\triangle P A 14 \_51020 \triangle P A 14 \_51010$ mutants were treated with $5 \mu \mathrm{g} / \mathrm{mL}$ tobramycin. At indicated time points the live bacteria numbers were determined by serial dilution and plating. (D) Wild-type PA14 and the $\triangle P A 14 \_51020$ mutant were treated with $0.5 \mu \mathrm{g} / \mathrm{mL}$ ciprofloxacin. At indicated time points the live bacteria numbers were determined by serial dilution and plating. ${ }^{* *}, p<0.01$ compared to the other samples by Student's $t$ test. (E) Total RNAs were isolated from the indicated strains at an $\mathrm{OD}_{600}$ of 1.0. The mRNA levels of PA14_51010 were determined by quantitative RT-PCR. The ribosomal protein coding gene $r p s L$ was used as an internal control. Data represent the results from three independent experiments. ${ }^{* *}, p<0.01$, ns, not significant, by Student's $t$ test. 


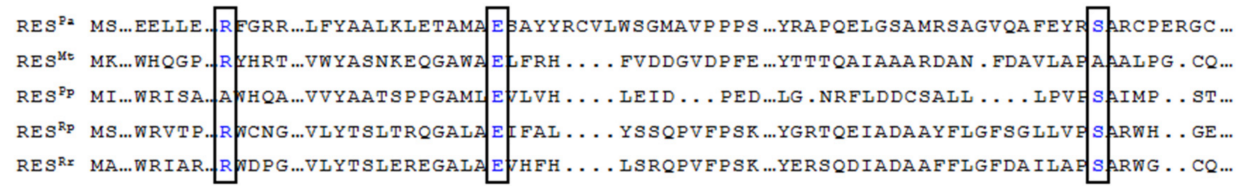

(A)

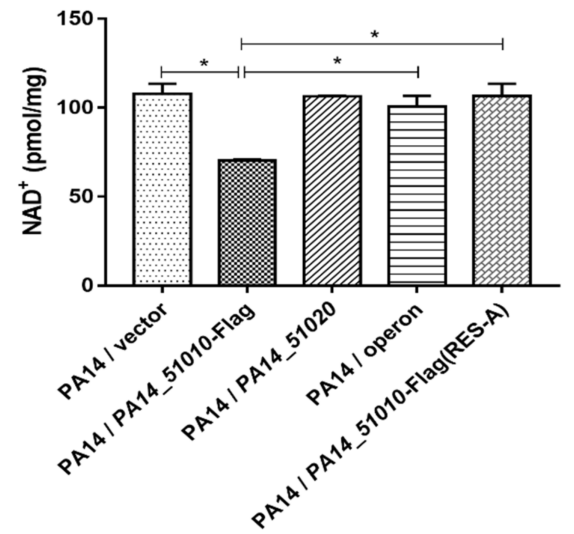

(B)

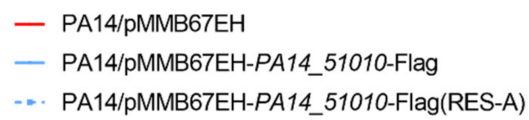

tobramycin

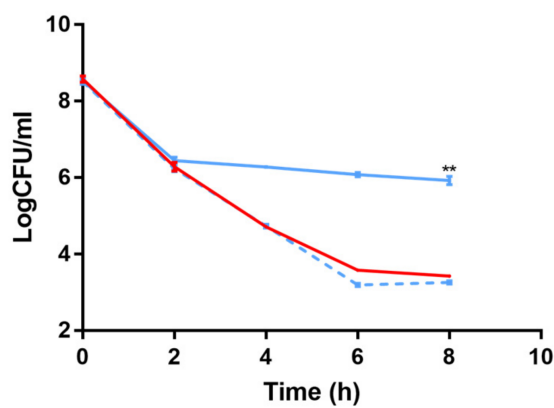

(D)

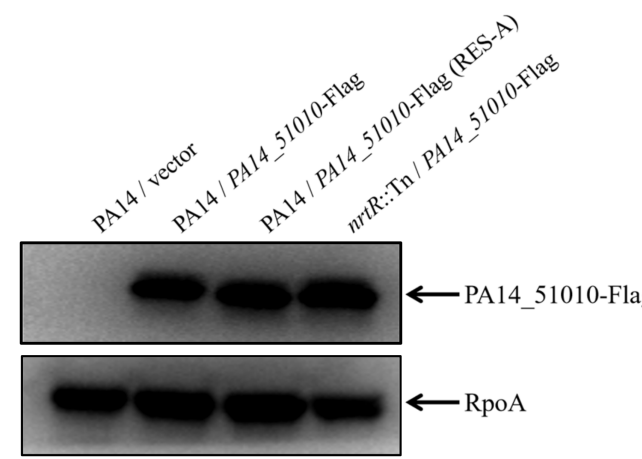

(C)

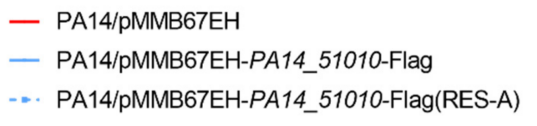

ciprofloxacin

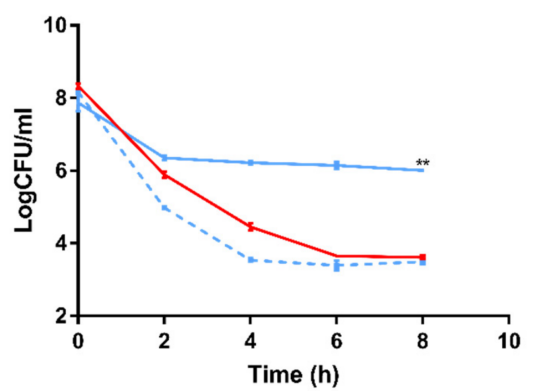

(E)

Figure 5. PA14_51010 promotes persister formation by reducing intracellular NAD ${ }^{+}$. (A) Protein sequence alignment of RES toxins from PA14 (RES ${ }^{\mathrm{Pa}}$ ), M. tuberculosis (RES ${ }^{\mathrm{Mt}}$ ), Pseudomonas putida KT2440 (RES Pp), Rhodopseudomonas palustris BisB18 (RES Rp) and Rhodospirillum rubrum ATCC 11170 (RES ${ }^{\mathrm{Rr}}$ ) by Dnaman. The conserved residues are shown in blue and boxed. (B) Wild-type PA14 carrying pMMB67EH, pMMB67EH-PA14_51010, pMMB67EH-PA14_51020, pMMB67EH-operon or pMMB67EH-PA14_51010 (RES-A) were cultured in LB to an $\mathrm{OD}_{600}$ of 1.0. The bacteria were collected by centrifugation, washed three times with phosphate buffered saline (PBS), and then lysed in an $\mathrm{NAD}^{+}$extracting buffer by sonication. The relative quantity of $\mathrm{NAD}^{+}$was normalized by the corresponding total protein amount. ${ }^{* *}, p<0.01$ by Student's $t$ test. (C) The levels of the PA14_51010-Flag in PA14/vector, PA14/PA14_51010-Flag, PA14/PA14_51010-Flag (RES-A) and nrtR::Tn/PA14_51010-Flag. (D,E) Wild-type PA14 carrying pMMB67EH, pMMB67EH-PA14_51010 or pMMB67EHPA14_51010 (RES-A) were treated with $5 \mu \mathrm{g} / \mathrm{mL}$ tobramycin (D) or $0.5 \mu \mathrm{g} / \mathrm{mL}$ ciprofloxacin (E). At indicated time points the live bacteria numbers were determined by serial dilution and plating. Data represent the results from three independent experiments. ${ }^{*}, p<0.05 ;{ }^{* *}, p<0.01$ compared to the other samples by Student's $t$ test. 


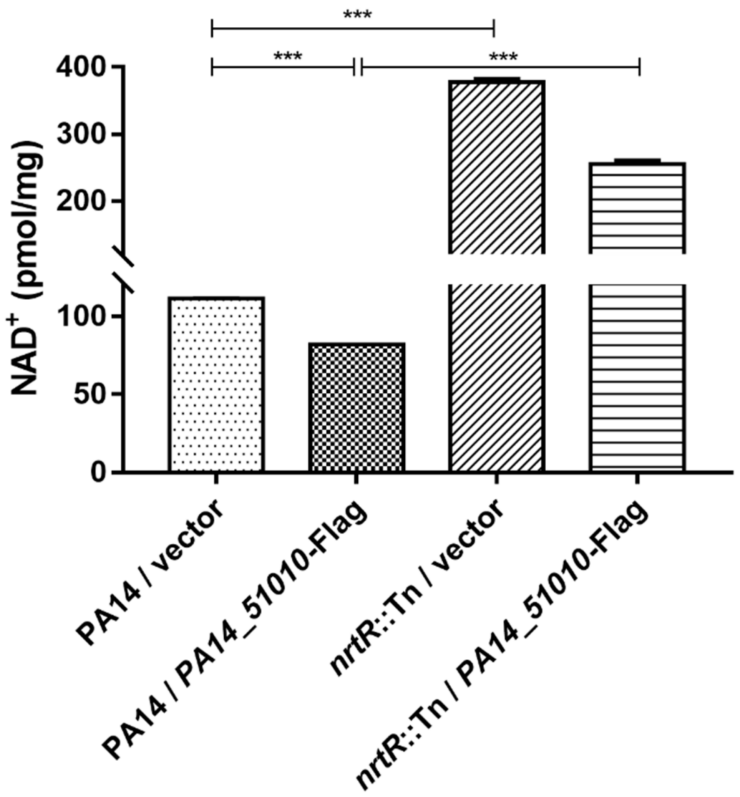

(A)

ciprofloxacin

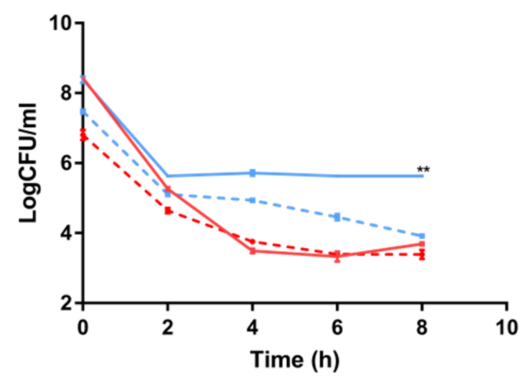

- PA14/PMMB67EH

- PA14/pMMB67EH-PA14_51010-Flag

-.. nrtR::Tn/PMMB67EH

-.. nrtR::Tn/pMMB67EH-PA14_51010-Flag

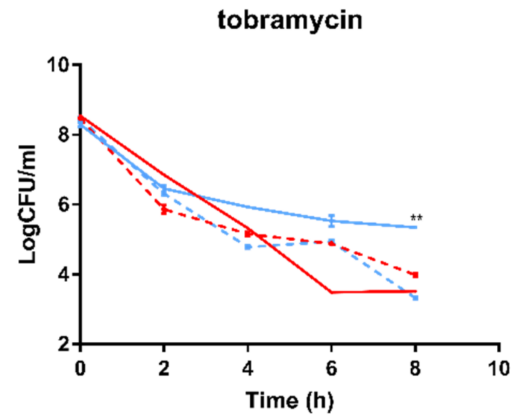

(B)

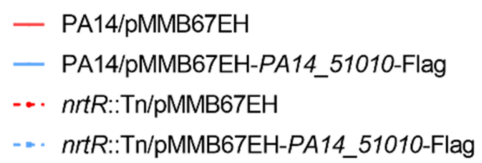

- PA14/pMMB67EH

-.. nrtR::Tn/pMMB67EH

- .. nrtR::Tn/pMMB67EH-PA14_51010-Flag

(C)

Figure 6. Over production of $\mathrm{NAD}^{+}$counteracts the effect of overexpression of PA14_51010 in persister formation. (A) Wild-type PA14 and the $n r t$ R::Tn mutant carrying pMMB67EH or pMMB67EH-PA14_51010-Flag were cultured in LB in the presence of $1 \mathrm{mM}$ IPTG to an $\mathrm{OD}_{600}$ of 1.0. The bacteria were collected by centrifugation and washed three times with PBS. The relative quantity of $\mathrm{NAD}^{+}$was normalized by the total protein amount. ${ }^{* *}, p<0.001$, by Student's $t$ test. (B,C) Wild-type PA14 and the $n r t R:: T n$ mutant carrying pMMB67EH or pMMB67EH-PA14_51010 were cultured in LB in the presence of $1 \mathrm{mM}$ IPTG to an $\mathrm{OD}_{600}$ of 1.0 . The bacteria were treated with $5 \mu \mathrm{g} / \mathrm{mL}$ tobramycin $(\mathbf{B}) \mathrm{or} 0.5 \mu \mathrm{g} / \mathrm{mL}$ ciprofloxacin (C). At indicated time points the live bacteria numbers were determined by serial dilution and plating. Data represent the results from three independent experiments. ${ }^{* *}, p<0.01$ compared to the other samples by Student's $t$ test.

\section{Discussion}

The developing antibiotic resistance of $P$. aeruginosa imposes a severe threat on human health all over the world [46-49]. It has been demonstrated that bacterial persister cells are able to form a reservoir for the development of antibiotic-resistant mutants [7,8]. TA systems have been shown to be involved in persister formation [9-12]. In this study we screened the predicted type II TA systems in P. aeruginosa wild-type strain PA14 and identified that PA14_51010-PA14_51020 modulates persister formation. PA14_51010 belongs to the RES family protein and our results reveal that it promotes persister formation by reducing the intracellular $\mathrm{NAD}^{+}$level. In Photorhabdus luminescens, Mycobacterium tuberculosis and Sinorhizobium meliloti, the cognate antitoxin of the RES toxin is named Xre (Xenobiotic response element) $[43,50]$. Based on the active domain and physiological function of 
PA14_51010 (PA1030 in PAO1), we propose to annotate it as ResA and the cognate antitoxin PA14_51020 (PA1029 in PAO1) as XreA.

$\mathrm{NAD}^{+}$is an electron carrier that participates in biological respiration and redox reactions and functions as a cofactor by $\mathrm{NAD}^{+}$-consuming enzymes. Therefore, reducing the intracellular level of $\mathrm{NAD}^{+}$by ResA might rewire the cell metabolism and interfere with the redox homeostasis, which might contribute to increased antibiotic tolerance. A recent study demonstrated that overexpression of a M. tuberculosis toxin MbcT in Mycobacterium smegmatis depleted the intracellular NAD+ and lead to cell death [51]. We suspect that ResA might display obvious growth inhibitory effects under certain environmental stresses such as carbon or amino acid starvation. It warrants further study to examine the conditions that trigger the expression and activation of ResA.

Thus far, at least five type II TA systems have been identified in P. aeruginosa, including ParD/ParE, HicA/HicB, RelE/RelB, HigB/HigA and ResA/XreA. ParE inhibits the function of DNA gyrase [25]. HigB has been found to cleave mRNA, which represses cell growths. Previous studies revealed that the toxin HigB affected swarming motility, pyochelin production, biofilm formation and expression of the type III secretion system (T3SS) genes, as well as numerous other genes in P. aeruginosa [28-30]. We demonstrated that HigB positively controlled three c-di-GMP hydrolysis genes. Thus, overexpression of higB reduces the intracellular level of c-di-GMP, resulting in upregulation of the T3SS genes and a reduction in biofilm formation [30]. Meanwhile, the cognate antitoxin HigA modulates the quorum-sensing systems by controlling the expression of MvfR independent of HigB [31]. It might be interesting to examine the roles of ResA/XreA in modulating global gene expression as well as the metabolic pathways.

Previously, we examined the gene expression profile of P. aeruginosa persister cells and found an operon composed of PA2282-PA2287 was upregulated. In the operon, PA2285 and PA2287 promote persister formation. We further demonstrated that PA2285 and PA2287 suppress transcription and cell division by directly binding to RNA polymerase and FtsZ [52].

Here, we demonstrated that the overexpression of res $A$ in wild-type PA14 increased the persister formation under tobramycin or ciprofloxacin treatment; however, deletion of the chromosomal resA did not affect the persister formation level. In E. coli and $S$. typhimurium, at least 37 TA systems have been identified [53]. Deletion of one of the TA systems did not affect the overall persister formation, presumably due to the redundancy of the TA systems $[54,55]$. Goormaghtigh et al. demonstrated that simultaneous deletion of 10 type II TA systems in E. coli did not affect the persister formation level under ampicillin or ofloxacin treatment [56]. It was demonstrated in Salmonella enterica that 14 type II TA systems were activated by nutrient starvation, phagocytosis by macrophages and transient acidification, which promoted persister formation [57]. However, simultaneous deletion of three TA systems (ecnB, phd-doc, and shpAB) did not affect persister formation [58]. These results suggest that additional TA systems or other determinants are involved in persister formation, which might compensate for the loss of one or multiple TA systems.

The alarmone molecule guanosine pentaphosphate/tetraphosphate, (p)ppGpp, has been shown to control the expression of TA systems and play important roles in persister formation as well as the bacterial response to environmental stresses, such as oxidative stress, starvation, etc. $[59,60]$. Meanwhile, it has been demonstrated that (p)ppGpp controls global gene expression and contributes to bacterial virulence in various infection models [61-63]. In P. aeruginosa, the role of (p)ppGpp in the regulation of the TA systems remains unknown. We previously demonstrated that the expression of hig $A$ was induced by ciprofloxacin treatment [29]. To further understand the roles of (p)ppGpp in the regulation of the identified TA systems and the bacterial response to antibiotics it is necessary to examine the transcriptomic profiles in wild-type and (p)ppGpp-deficient strains in the presence and absence of antibiotics.

Overall, our study revealed a novel type II TA system that modulated persister formation in P. aeruginosa. 
Supplementary Materials: The following are available online at https:/ / www.mdpi.com/article/10 .3390 / microorganisms 9040753 /s1, Figure S1: Change of the start codon of the PA14_51010 gene from the original GTG to ATG reduced the bacterial growth rate.

Author Contributions: Conceptualization, J.Z. and W.W.; methodology, J.Z.; software, J.Z.; investigation, J.Z., S.L., and H.L.; resources, J.Z.; data curation, J.Z., S.L., and Y.J.; writing-original draft preparation, J.Z. and W.W.; writing-review and editing, J.Z., Y.J., F.B., Z.C., and W.W.; supervision, W.W.; funding acquisition, Y.J., F.B., Z.C., and W.W. All authors have read and agreed to the published version of the manuscript.

Funding: This research was funded by the National Key Research and Development Project of China (2017YFE0125600), National Science Foundation of China (31970179, 31970680, 31900115 and 31870130), and the Tianjin Municipal Science and Technology Commission (19JCYBJC24700).

Institutional Review Board Statement: Not applicable.

Data Availability Statement: Data is contained within the article.

Conflicts of Interest: The authors declare no conflict of interest. The funders had no role in the design of the study; in the collection, analyses, or interpretation of data; in the writing of the manuscript; or in the decision to publish the results.

\section{References}

1. Wood, T.K. Combatting bacterial persister cells. Biotechnol. Bioeng. 2015, 113, 476-483. [CrossRef]

2. Paranjape, S.S.; Shashidhar, R. Comparison of Starvation-Induced Persister Cells with Antibiotic-Induced Persister Cells. Curr. Microbiol. 2019, 76, 1495-1502. [CrossRef] [PubMed]

3. Fisher, R.A.; Gollan, B.; Helaine, S. Persistent bacterial infections and persister cells. Nat. Rev. Genet. 2017, 15, 453-464. [CrossRef] [PubMed]

4. Vallette, F.M.; Olivier, C.; Lézot, F.; Oliver, L.; Cochonneau, D.; Lalier, L.; Cartron, P.-F.; Heymann, D. Dormant, quiescent, tolerant and persister cells: Four synonyms for the same target in cancer. Biochem. Pharmacol. 2019, 162, 169-176. [CrossRef] [PubMed]

5. Balaban, N.Q.; Merrin, J.; Chait, R.; Kowalik, L.; Leibler, S. Bacterial persistence as a phenotypic switch. Science 2004, 305, 1622-1625. [CrossRef] [PubMed]

6. Cohen, N.R.; Lobritz, M.A.; Collins, J.J. Microbial persistence and the road to drug resistance. Cell Host Microbe 2013, 13, 632-642. [CrossRef] [PubMed]

7. Levin-Reisman, I.; Ronin, I.; Gefen, O.; Braniss, I.; Shoresh, N.; Balaban, N.Q. Antibiotic tolerance facilitates the evolution of resistance. Science 2017, 355, 826-830. [CrossRef] [PubMed]

8. Sebastian, J.; Swaminath, S.; Nair, R.R.; Jakkala, K.; Pradhan, A.; Ajitkumar, P. De novo emergence of genetically resistant mutants of mycobacterium tuberculosis from the persistence phase cells formed against antituberculosis drugs in vitro. Antimicrob. Agents Chemother. 2017, 61, e01343-16. [CrossRef]

9. Page, R.; Peti, W. Toxin-antitoxin systems in bacterial growth arrest and persistence. Nat. Chem. Biol. 2016, 12, 208-214. [CrossRef]

10. Kim, J.-S.; Heo, P.; Yang, T.-J.; Lee, K.-S.; Cho, D.-H.; Kim, B.T.; Suh, J.-H.; Lim, H.-J.; Shin, D.; Kim, S.-K.; et al. Selective killing of bacterial persisters by a single chemical compound without affecting normal antibiotic-sensitive cells. Antimicrob. Agents Chemother. 2011, 55, 5380-5383. [CrossRef]

11. Svenningsen, M.S.; Veress, A.; Harms, A.; Mitarai, N.; Semsey, S. Birth and Resuscitation of (p)ppGpp Induced Antibiotic Tolerant Persister Cells. Science Rep. 2019, 9, 6056. [CrossRef]

12. Wen, Y.; Behiels, E.; Devreese, B. Toxin-Antitoxin systems: Their role in persistence, biofilm formation, and pathogenicity. Pathog. Dis. 2014, 70, 240-249. [CrossRef]

13. Schuster, C.F.; Bertram, R. Toxin-antitoxin systems are ubiquitous and versatile modulators of prokaryotic cell fate. FEMS Microbiol. Lett. 2013, 340, 73-85. [CrossRef]

14. García-Contreras, R.; Zhang, X.-S.; Kim, Y.; Wood, T.K. Protein translation and cell death: The role of rare tRNAs in biofilm formation and in activating dormant phage killer genes. PLoS ONE 2008, 3, e2394. [CrossRef]

15. Marimon, O.; Teixeira, J.M.C.; Cordeiro, T.N.; Soo, V.W.C.; Wood, T.L.; Mayzel, M.; Amata, I.; García, J.; Morera, A.; Gay, M.; et al. An oxygen-sensitive toxin-antitoxin system. Nat. Commun. 2016, 7, 13634. [CrossRef]

16. Yu, X.; Gao, X.; Zhu, K.; Yin, H.; Mao, X.; Wojdyla, J.A.; Qin, B.; Huang, H.; Wang, M.; Sun, Y.-C.; et al. Characterization of a toxin-antitoxin system in Mycobacterium tuberculosis suggests neutralization by phosphorylation as the antitoxicity mechanism. Commun. Biol. 2020, 3, 216. [CrossRef]

17. Yao, J.; Zhen, X.; Tang, K.; Liu, T.; Xu, X.; Chen, Z.; Guo, Y.; Liu, X.; Wood, T.K.; Ouyang, S.; et al. Novel polyadenylylationdependent neutralization mechanism of the HEPN/MNT toxin/antitoxin system. Nucleic Acids Res. 2020, 48, 11054-11067. [CrossRef]

18. Wang, X.; Yao, J.; Sun, Y.-C.; Wood, T.K. Type VII toxin/antitoxin classification system for antitoxins that enzymatically neutralize toxins. Trends Microbiol. 2020. [CrossRef] 
19. Syed, M.A.; Lévesque, C.M. Chromosomal bacterial type II toxin-antitoxin systems. Can. J. Microbiol. 2012, 58, 553-562. [CrossRef]

20. Sala, A.; Bordes, P.; Genevaux, P. Multiple toxin-antitoxin systems in Mycobacterium tuberculosis. Toxins 2014, 6, 1002-1020. [CrossRef]

21. Fraikin, N.; Goormaghtigh, F.; Van Melderen, L. Type II Toxin-Antitoxin Systems: Evolution and revolutions. J. Bacteriol. 2020, 202, e00763-19. [CrossRef] [PubMed]

22. Moradali, M.F.; Ghods, S.; Rehm, B.H.A. Pseudomonas aeruginosa Lifestyle: A paradigm for adaptation, survival, and persistence. Front. Cell. Infect. Microbiol. 2017, 7, 39. [CrossRef]

23. Viducic, D.; Ono, T.; Murakami, K.; Susilowati, H.; Kayama, S.; Hirota, K.; Miyake, Y. Functional Analysis ofspoT, relA and $d k s A$ Genes on quinolone tolerance in Pseudomonas aeruginosa under nongrowing condition. Microbiol. Immunol. 2006, 50, 349-357. [CrossRef]

24. Soares, A.; Alexandre, K.; Etienne, M. Tolerance and persistence of Pseudomonas aeruginosa in biofilms exposed to antibiotics: Molecular mechanisms, antibiotic strategies and therapeutic perspectives. Front. Microbiol. 2020, 11, 2057. [CrossRef]

25. Muthuramalingam, M.; White, J.C.; Murphy, T.; Ames, J.R.; Bourne, C.R. The toxin from a ParDE toxin-antitoxin system found in Pseudomonas aeruginosa offers protection to cells challenged with anti-gyrase antibiotics. Mol. Microbiol. 2018, 111, 441-454. [CrossRef]

26. Li, G.; Shen, M.; Lu, S.; Le, S.; Tan, Y.; Wang, J.; Zhao, X.; Shen, W.; Guo, K.; Yang, Y.; et al. Identification and characterization of the HicAB Toxin-Antitoxin System in the opportunistic pathogen Pseudomonas aeruginosa. Toxins 2016, 8, 113. [CrossRef]

27. Coskun, U.S.S. Effect of mazEF, higBA and relBE Toxin-Antitoxin Systems on antibiotic resistance in Pseudomonas aeruginosa and Staphylococcus isolates. Malawi Med. J. 2018, 30, 67-72. [CrossRef]

28. Wood, T.L.; Wood, T.K. The HigB/HigA toxin/antitoxin system of Pseudomonas aeruginosa influences the virulence factors pyochelin, pyocyanin, and biofilm formation. Microbiologyopen 2016, 5, 499-511. [CrossRef]

29. Li, M.; Long, Y.; Liu, Y.; Liu, Y.; Chen, R.; Shi, J.; Zhang, L.; Jin, Y.; Yang, L.; Bai, F.; et al. HigB of Pseudomonas aeruginosa enhances killing of phagocytes by up-regulating the Type III secretion system in ciprofloxacin induced persister cells. Front. Cell. Infect. Microbiol. 2016, 6, 125. [CrossRef]

30. Zhang, Y.; Xia, B.; Li, M.; Shi, J.; Long, Y.; Jin, Y.; Bai, F.; Cheng, Z.; Jin, S.; Wu, W. HigB reciprocally controls biofilm formation and the expression of Type III Secretion System Genes through Influencing the Intracellular c-di-GMP level in Pseudomonas aeruginosa. Toxins 2018, 10, 424. [CrossRef]

31. Guo, Y.; Sun, C.; Li, Y.; Tang, K.; Ni, S.; Wang, X. Antitoxin HigA inhibits virulence gene mvfR expression in Pseudomonas aeruginosa. Environ. Microbiol. 2019, 21, 2707-2723. [CrossRef] [PubMed]

32. Liberati, N.T.; Urbach, J.M.; Miyata, S.; Lee, D.G.; Drenkard, E.; Wu, G.; Villanueva, J.; Wei, T.; Ausubel, F.M. An ordered, nonredundant library of Pseudomonas aeruginosa strain PA14 transposon insertion mutants. Proc. Natl. Acad. Sci. USA 2006, 103, 2833-2838. [CrossRef] [PubMed]

33. Choi, K.-H.; Schweizer, H.P. mini-Tn7 insertion in bacteria with single attTn7 sites: Example Pseudomonas aeruginosa. Nat. Protoc. 2006, 1, 153-161. [CrossRef] [PubMed]

34. Fürste, J.P.; Pansegrau, W.; Frank, R.; Blöcker, H.; Scholz, P.; Bagdasarian, M.; Lanka, E. Molecular cloning of the plasmid RP4 primase region in a multi-host-range tacP expression vector. Gene 1986, 48, 119-131. [CrossRef]

35. Chen, R.; Wei, X.; Li, Z.; Weng, Y.; Xia, Y.; Ren, W.; Wang, X.; Jin, Y.; Bai, F.; Cheng, Z.; et al. Identification of a small RNA that directly controls the translation of the quorum sensing signal synthase gene rhll in Pseudomonas aeruginosa. Environ. Microbiol. 2019, 21, 2933-2947. [CrossRef]

36. Xia, B.; Li, M.; Tian, Z.; Chen, G.; Liu, C.; Xia, Y.; Jin, Y.; Bai, F.; Cheng, Z.; Jin, S.; et al. Oligoribonuclease contributes to tolerance to aminoglycoside and $\beta$-Lactam antibiotics by regulating KatA in Pseudomonas aeruginosa. Antimicrob. Agents Chemother. 2019, 63, e00212-19. [CrossRef]

37. Hoang, T.T.; Karkhoff-Schweizer, R.R.; Kutchma, A.J.; Schweizer, H.P. A broad-host-range Flp-FRT recombination system for site-specific excision of chromosomally-located DNA sequences: Application for isolation of unmarked Pseudomonas aeruginosa mutants. Gene 1998, 212, 77-86. [CrossRef]

38. Weng, Y.; Chen, F.; Liu, Y.; Zhao, Q.; Chen, R.; Pan, X.; Liu, C.; Cheng, Z.; Jin, S.; Jin, Y.; et al. Pseudomonas aeruginosa enolase influences bacterial tolerance to oxidative stresses and virulence. Front. Microbiol. 2016, 7, 1999. [CrossRef]

39. Sun, Z.; Shi, J.; Liu, C.; Jin, Y.; Li, K.; Chen, R.; Jin, S.; Wu, W. PrtR Homeostasis Contributes to Pseudomonas aeruginosa pathogenesis and resistance against ciprofloxacin. Infect. Immun. 2014, 82, 1638-1647. [CrossRef]

40. Winsor, G.L.; Griffiths, E.J.; Lo, R.; Dhillon, B.K.; Shay, J.A.; Brinkman, F.S.L. Enhanced annotations and features for comparing thousands of Pseudomonas genomes in the Pseudomonas genome database. Nucleic Acids Res. 2016, 44, D646-D653. [CrossRef]

41. Skjerning, R.B.; Senissar, M.; Winther, K.S.; Gerdes, K.; Brodersen, D.E. The RES domain toxins of RES-Xre toxin-antitoxin modules induce cell stasis by degrading NAD+. Mol. Microbiol. 2018, 111, 221-236. [CrossRef]

42. Freire, D.M.; Gutierrez, C.; Garza-Garcia, A.; Grabowska, A.D.; Sala, A.J.; Ariyachaokun, K.; Panikova, T.; Beckham, K.S.; Colom, A.; Pogenberg, V.; et al. An NAD+ phosphorylase toxin triggers Mycobacterium tuberculosis cell death. Mol. Cell 2019, 73, 1282-1291. [CrossRef]

43. Gazzaniga, F.; Stebbins, R.; Chang, S.Z.; McPeek, M.A.; Brenner, C. Microbial NAD metabolism: Lessons from comparative genomics. Microbiol. Mol. Biol. Rev. 2009, 73, 529-541. [CrossRef] 
44. Gao, R.; Wei, W.; Hassan, B.H.; Li, J.; Deng, J.-Y.; Feng, Y. A single regulator NrtR controls bacterial NAD+ homeostasis via its acetylation. eLife 2019, 8, e51603. [CrossRef]

45. Okon, E.; Dethlefsen, S.; Pelnikevich, A.; Van Barneveld, A.; Munder, A.; Tümmler, B. Key role of an ADP-ribose-Dependent transcriptional regulator of NAD metabolism for fitness and virulence of Pseudomonas aeruginosa. Int. J. Med Microbiol. 2017, 307, 83-94. [CrossRef]

46. Gad, G.F.; El-Domany, R.A.; Ashour, H.M. Antimicrobial Susceptibility Profile of Pseudomonas aeruginosa Isolates in Egypt. J. Urol. 2008, 180, 176-181. [CrossRef]

47. Elkhatib, W.F.; Khalil, M.A.; Ashour, H.M. Integrons and antiseptic resistance genes mediate resistance of Acinetobacter baumannii and Pseudomonas aeruginosa Isolates from intensive care unit patients with wound infections. Curr. Mol. Med. 2019, 19, 286-293. [CrossRef]

48. Mann, D.L.; Foale, R.A.; Gillam, L.D.; Schoenfeld, D.; Newell, J.; Weyman, A.E. Early natural history of regional left ventricular dysfunction after experimental myocardial infarction. Am. Heart J. 1988, 115, 538-546. [CrossRef]

49. Ma, Y.; Wang, C.; Li, Y.; Li, J.; Wan, Q.; Chen, J.; Tay, F.R.; Niu, L. Considerations and caveats in combating ESKAPE pathogens against nosocomial infections. Adv. Sci. 2019, 7, 1901872. [CrossRef]

50. Xie, Y.; Wei, Y.; Shen, Y.; Li, X.; Zhou, H.; Tai, C.; Deng, Z.; Ou, H.-Y. TADB 2.0: An updated database of bacterial Type II Toxin-Antitoxin loci. Nucleic Acids Res. 2018, 46, D749-D753. [CrossRef]

51. Ariyachaokun, K.; Grabowska, A.D.; Gutierrez, C.; Neyrolles, O. Multi-Stress induction of the Mycobacterium tuberculosis MbcTA bactericidal toxin-antitoxin system. Toxins 2020, 12, 329. [CrossRef]

52. Long, Y.; Fu, W.; Li, S.; Ren, H.; Li, M.; Liu, C.; Zhang, B.; Xia, Y.; Fan, Z.; Xu, C.; et al. Identification of novel genes that promote persister formation by repressing transcription and cell division in Pseudomonas aeruginosa. J. Antimicrob. Chemother. 2019, 74, 2575-2587. [CrossRef]

53. Harms, A.; Maisonneuve, E.; Gerdes, K. Mechanisms of bacterial persistence during stress and antibiotic exposure. Science 2016, 354, aaf4268. [CrossRef]

54. Lewis, K. Persister Cells. Annu. Rev. Microbiol. 2010, 64, 357-372. [CrossRef]

55. Shan, Y.; Lazinski, D.; Rowe, S.; Camilli, A.; Lewis, K. Genetic Basis of Persister Tolerance to Aminoglycosides in Escherichia coli. mBio 2015, 6, e00078-15. [CrossRef]

56. Goormaghtigh, F.; Fraikin, N.; Putrinš, M.; Hallaert, T.; Hauryliuk, V.; Garcia-Pino, A.; Sjödin, A.; Kasvandik, S.; Udekwu, K.; Tenson, T; et al. Reassessing the role of type II toxin-antitoxin systems in formation of Escherichia coli type II persister cells. $m$ Bio 2018, 9, e00640-18. [CrossRef]

57. Helaine, S.; Cheverton, A.M.; Watson, K.G.; Faure, L.M.; Matthews, S.A.; Holden, D.W. Internalization of Salmonella by macrophages induces formation of nonreplicating persisters. Science 2014, 343, 204-208. [CrossRef] [PubMed]

58. Claudi, B.; Spröte, P.; Chirkova, A.; Personnic, N.; Zankl, J.; Schürmann, N.; Schmidt, A.; Bumann, D. Phenotypic variation of Salmonella in host tissues delays eradication by antimicrobial chemotherapy. Cell 2014, 158, 722-733. [CrossRef]

59. Pacios, O.; Blasco, L.; Bleriot, I.; Fernandez-Garcia, L.; Ambroa, A.; López, M.; Bou, G.; Cantón, R.; Garcia-Contreras, R.; Wood, T.K.; et al. (p)ppGpp and its role in bacterial persistence: New challenges. Antimicrob. Agents Chemother. 2020, 64, e01283-20. [CrossRef]

60. Stewart, P.S.; Franklin, M.J.; Williamson, K.S.; Folsom, J.P.; Boegli, L.; James, G.A. Contribution of stress responses to antibiotic tolerance in Pseudomonas aeruginosa biofilms. Antimicrob. Agents Chemother. 2015, 59, 3838-3847. [CrossRef]

61. Xu, X.; Yu, H.; Zhang, D.; Xiong, J.; Qiu, J.; Xin, R.; He, X.; Sheng, H.; Cai, W.; Jiang, L.; et al. Role of ppGpp in Pseudomonas aeruginosa acute pulmonary infection and virulence regulation. Microbiol. Res. 2016, 192, 84-95. [CrossRef] [PubMed]

62. Vogt, S.L.; Green, C.; Stevens, K.M.; Day, B.; Erickson, D.L.; Woods, D.E.; Storey, D.G. The stringent response is essential for Pseudomonas aeruginosa virulence in the rat lung agar bead and drosophila melanogaster feeding models of infection. Infect. Immun. 2011, 79, 4094-4104. [CrossRef] [PubMed]

63. Pletzer, D.; Blimkie, T.M.; Wolfmeier, H.; Li, Y.; Baghela, A.; Lee, A.H.Y.; Falsafi, R.; Hancock, R.E.W. The stringent stress response controls proteases and global regulators under optimal growth conditions in Pseudomonas aeruginosa. mSystems 2020, 5, e00495-20. [CrossRef] [PubMed] 